\title{
LITERATURE AND SPIRITUALITY IN THE POST-SECULAR AGE
}

\author{
Faisal Nazir"
}

\begin{abstract}
This paper attempts to reconsider the nature and function of the 'spiritual' dimension in literary texts and in literary study in the context of the present state of the discipline of literary studies. The present era is often defined as a 'post-secular' era, one in which themes of spirituality and mysticism are increasingly noticeable in literary works. The paper argues that to maintain its relevance to contemporary writers and readers, literary criticism has to (re-)address these themes in a concrete and effective way. The paper recommends a comparative approach to the discussion of spirituality and mysticism in contemporary literature and literary criticism. In order to carry effective analytical potential, this approach, the paper emphasizes, has to be developed from specific spiritual traditions. The paper first discusses the disciplinary crisis literary studies have always been exposed to since their inception as a discipline of study in academic institutes. It then reviews the current state of the discipline and describes how the discipline came to be dominated by scientific and social approaches. Finally, it suggests the reinstitution of the 'spiritual' element in literary study as a way out from the state of crisis in the discipline of literary studies. The paper thus attempts to strengthen the disciplinary identify of literary studies while exploring interdisciplinary aspects of the study literature.
\end{abstract}

Keywords: literary studies, literary theory, spirituality, structuralism, post-structuralism, aesthetics

I would like to begin by noting the strange disparity that exists between the current states of the literary market and the academic discipline of literary studies. Each year, numerous literature festivals are held around the world, a few of them in Pakistan and India such as Karachi, Lahore, and Islamabad Literature Festivals, and in India the well known Jaipur Literature Festival, the Lucknow Literature Festival and the Chandigarh Literature Festival. There are a number of awards and prizes given to authors of literary works, including the Nobel Prize, the Booker Prize, the Commonwealth Literature Prize, and the Pulitzer Prize. Hundreds of literary works are published in the world each year. And yet, when it comes to the academic study of literature, the key word that defines its state is 'crisis'. In this paper I have tried to make some sense of this strange crisis that the study of literature faces today and to suggest some ways of dealing with this crisis. The paper begins with establishing the contemporary context of literary studies and then traces the history of the crisis it faces today since its inception under the influence of

* Faisal Nazir, Ph.D. Assistant Professor, Department of English, University of Karachi 
Matthew Arnold and FR Leavis. Finally, it suggests some ways of dealing with the crisis in literary studies.

Having gone through the linguistic turn, the cultural turn, and the ethical turn, is the study of literature going through yet another turn which may be described as a 'spiritual' turn? Is it a turn or a return - a return to something which was conceived as the distinctive dimension of the study of literature at its inception and was described as 'humanism'? How does this (re-)turn affect the academic study of literature? Does it require a repositioning of the social and political approaches to the study of literature which have been occupying the central place in the study programme since the cultural turn in literary studies in the 1980s? Or is this 'spiritual' approach to be placed alongside such 'materialist' approaches to the study of literature as Marxism, Historicism, Cultural Materialism, Feminism and Postcolonialism as a sort of alternative approach in the literary studies programme? What learning objectives and outcomes will such an approach seek to achieve? How will this approach contribute to the larger society and public interests? These are the questions which this paper seeks to deal with and to suggest in what ways a 'spiritual' approach can be (re-)institutionalized.

Among the many 'posts' that characterize our present era - e.g. the postmodern, the postcolonial, the post-industrial - one 'post' that is gaining increasing scholarly attention is the 'post-secular'. According to Gorski et al, "From the writings of Jürgen Habermas on the role of religion in public life to a host of more theoretical reflections on religion in contemporary society, the idea of the post-secular has acquired increasing currency in contemporary academic discussions" (Gorski, Kim, Tarpey, \& VanAntwerpen, 2012). Though the increased visibility of religion in the public sphere is one reason for conceptualizing the present era as a 'post-secular' one, religion is approached in a diversity of ways by scholars in social sciences and the humanities. These ways are not restricted to religion (a set of beliefs, doctrines, and rituals) as such but include 'the religious' - the frequent use of religious language and symbols in what Reder and Schmidt define as "other, not genuinely religious, domains" (Reder \& Schmidt, 2010). Referring to "[u]nmistakable borrowings from religious traditions ... in film, theatre and advertisement" Reder and Schmidt state that "the semantic and symbolic potentials of religions are becoming a universal social resource which shapes public and cultural life in a whole variety of ways" (Reder \& Schmidt, 2010).

In this rather diffused sense, religion and religious vocabulary has pervaded almost all the facets of personal and social life of individuals, thus rendering the term 'postsecular' a valid description of the present age. Yet, 'post-secular' remains a rather vague term which, according to James Beckford, "has at times been used uncritically" (Beckford, 2012). According to Beckford (2012), there is a "growing variety of meanings attributed to "postsecularity" and, therefore, "the need to manage the sheer variety has become pressing." In Beckford's view "concern with the postsecular is strongest in theology and religious studies, philosophy, literary theory, postcolonial studies, sociology, anthropology, political science, international relations, and geography" (Beckford, 2012). However, among these disciplines, it is within the study of arts that "[s]ome of the most innovative and imaginative reasons for thinking in terms of the postsecular have emerged ...." (Beckford, 2012). 
More specifically, it is in the field of literary studies that an engagement with the postsecular is most prominent. Taking the post-secular to mean a "'return' of the religious in literary studies," Bradley, Carruthers and Tate assert that "literature constitutes a privileged space in which the return of the religious can take place" since "[1]iterature, like religion, has always implied a challenge to strict boundaries - between fantasy and fact, transcendence and immanence, the spiritual and the material" (Bradley, Carruthers, \& Tate, 2010). In their view, literary ('secular') writing "has always gestured towards the spiritual, to its religious heritages and the numinous nature of so much of human experience" (Bradley, Carruthers, \& Tate, 2010). In particular, "postmodern literature is almost by definition concerned with questions of truth, narrative and simulation" and contrary to the general opinion in which it is associated with "licensing an untrammeled irony, play or skepticism", it is rather "a way of re-opening debates that can only be described as theological ..." (Bradley, Carruthers, \& Tate, 2010). For Bradley, Carruthers and Tate (2010), "the literary remains revelatory, a source of inspiration, a place in which truth can be fought over and even redeemed."

If literary writing has become once again concerned with religion and religious questions, what about the study of literature? Should there be a turn to religion in literary studies as well? I will argue that this turn to religion, if it takes place, will be only a return and not a new turn in literary studies. To support my argument, I will take a look at how the academic study of literature was conceptualized in the writings of two of the most influential scholars in the formation of the discipline of literary studies, Matthew Arnold and FR Leavis.

Ever since its establishment in the early $20^{\text {th }}$ century, the study of literature, or more specifically, English literature, has been closely connected with social and cultural concerns. Far from aiming at studying literature for its own sake, the study of literature was supposed to cultivate and preserve cultural values. This particular conception of the purpose and function of literary studies shows the great influence of the writings and ideas of Matthew Arnold, a $19^{\text {th }}$ century educationist and literary scholar, on the development and institutionalization of literary studies in England. In Arnold's view, religion was, in a sense, to be displaced by culture, and the sacred texts to be displaced by literary texts. According to Arnold,

\begin{abstract}
We should conceive of poetry worthily, and more highly than it has been the custom to conceive of it. We should conceive of it as capable of higher uses, and called to higher destinies, than those which in general men have assigned to it hitherto. More and more mankind will discover that we have to turn to poetry to interpret life for us, to console us, to sustain us. Without poetry, our science will appear incomplete; and most of what now passes with us for religion and philosophy will be replaced by poetry. (Arnold, 1880/2004)
\end{abstract}

In saying that we should 'conceive' of poetry as 'capable of higher uses' Arnold was proposing a particular use of poetry or literature, and in proposing this, Arnold was, in a sense, charting out the aims and objectives of the study of poetry or literature. Poetry was to be used to 'interpret life for us, to console us, to sustain us.' In pursuing these aims, poetry was to be made a substitute of religion and science, but of religion in 
particular, as interpreting life, and offering consolation and sustenance to human beings are tasks that have traditionally been performed by religion.

Religion was, thus, not to be opposed by poetry/literature but to be displaced. And since literature was to perform the functions of religion, the study of literature was also to be built on a religious model. According to Howard Felperin, "When it began in the nineteenth century, the study of European vernacular literature modeled itself on the long established study of Biblical and classical texts, taking over the methods of its precursors, while adapting them to new aims" (Felperin, 1985). The object of study of this literature programme was to be the literary 'canon', again an idea derived from the study of religion where the sacred or 'canonical' books are the objects of study. The main task of literary criticism, thus, became the interpretation of literary works which in their turn were interpretations of life. This aligned literary criticism with the religious tradition of hermeneutics. According to Stephen Prickett:

\begin{abstract}
The importance of ... biblical interpretation on the subsequent development of European literature and criticism cannot be overestimated. Until almost the end of the eighteenth century the literal meaning of the Bible was seen as being only one among many ways of understanding it. Not merely did allegorical, figural and typological modes of reading coexist with the literal one, they were often in practice (if not in theory) accorded higher status. Since the Bible was the model for all secular literature such ways of reading naturally became the model for the way in which all books were to be read. (Prickett, 1990)
\end{abstract}

However, while religion is concerned with transforming and organizing the spiritual life of human beings and holds for them the offer of a final salvation from suffering and dejection, the study of literature could only offer a modest 'cultural salvation' at best and at worst an acceptance of suffering and dejection as the inevitable human condition ('to console us, to sustain us'). The study of literature was, therefore, cultural in nature right from its conception in the writings of Arnold. Culture was the central concern of Arnold as is evident from his book Culture and Anarchy. According to Jane Garnett:

The project of writing the essays was a very serious one for Arnold, who wanted to establish his credibility as a cultural critic of society as a whole, to ensure that his ideas made an impact, and to dispel accusations of dilettantism. He wanted to defend his role as a thinker, rather than a doer (in the political sense), but, in so doing, to promote the idea of culture as an active principle, an approach to life - as the engaged thought without which action was futile. (Garnett, 2006)

This concern with and for culture in the study of literature found an even stronger representative in FR Leavis in whose work and through whose influence this approach to the study of literature was institutionalized. While Matthew Arnold had identified culture as, among other things, 'the best that has been thought and said in the world', which may be taken to refer to the literary 'canon', a group of texts, Leavis went even further and restricted culture to a 'minority' of individuals whose responsibility it was to preserve culture from corruption and decline. In "Mass Civilization and Minority Culture" he wrote: 
The minority capable not only of appreciating Dante, Shakespeare, Donne, Baudelaire, Hardy (to take major instances) but of recognizing their latest successors constitute the consciousness of the race (or of a branch of it) at a given time ... Upon this minority depends our power of profiting by the finest human experience of the past; they keep alive the subtlest and most perishable parts of tradition. Upon them depend the implicit standards that order the finer living of an age, the sense that this is worth more than that, this rather than that is the direction in which to go, the centre is here rather than there. (Leavis qtd. in Storer, 2009)

For Leavis, this cultural elitism is firmly grounded in sensitivity to literature and literary language. He writes,

In their [the minority's] keeping, to use a metaphor that is metonymy also and will bear a good deal of pondering, is the language, the changing idiom, upon which fine living depends, and without which distinction of spirit is thwarted and incoherent. By 'culture' I mean the use of such a language. (Leavis qtd. in Storer, 2009)

By 'language ... upon which fine living depends' Leavis is clearly referring to 'literary' language and in saying that culture is the possession of or sensitivity to literary language, Leavis is establishing literature and culture as identical entities. For Leavis then, the study of literature was, the study of culture but culture understood, as Edward Said explains, as having "a refining and elevating element, each society's reservoir of the best that has been known and thought, as Arnold put it in the 1860s" (Said, 1994).

Thus, what gave literary works their special privilege was literary language. Consequently, the most appropriate method for the study of literature came to be seen as 'close reading'. In Leavis's view, this was not a matter of choice but an answer to the demand made by literary works upon the reader. In his essay "Literary Criticism and Philosophy", Leavis identified close reading as an approach that was completely in accord with the nature of literary works. He writes:

The reading demanded by poetry is of a different kind from that demanded by philosophy ... Words in poetry invite us, not to 'think about' and judge but to 'feel into' or 'become'- to realize a complex experience that is given in the words. They demand, not merely a fuller-bodied response, but a completer responsiveness .... (Leavis, Literary Criticism and Philosophy, 1937/1997)

This view of literature and literary language remained central to the academic study of literature until the discipline of the humanities went through what is described as the 'linguistic turn'. Based on the writings of Ferdinand de Saussure, the linguistic turn made language not only the central theme in philosophy, but also made language in the Saussurian sense the conceptual model for understanding all cultural phenomena, from myth to sports and from literature to fashion. This mode of analysis used most extensively by Claude Levi Strauss and Roland Barthes gave rise to the intellectual movement known as Structuralism. However, paradoxically, this very movement which made language central to all humanistic study, made the concept of 'literary' language in its Leavisian sense appear suspect when subjected to the structuralist analysis. This 
was done by attempts to explain the 'literary' element in works of literature which was then found to be not the exclusive property of literary works but to be universally present in all uses of language. Such 'literary' devices as metaphor, simile, irony, paradox, personification were found to be a regular part of all language use whether it is the language of social conversation, or journalism, or advertising. Thus, the privilege accorded to literary works because of their 'literariness' was questioned.

Moreover, structuralism also took away the almost mystical, 'humanizing' quality attributed to literature by the liberal humanists. The structuralists analyzed literature just as any other system of signs and concepts, in order to develop a scientific understanding of literature. In the structuralist approach, literature came to be seen as constituted by patterns and 'codes' which could be classified and seen in relation to each other and also in their relation to the literary work as a whole. The most relevant example here is Roland Barthes' study $S / Z$ of Balzac's novella Sarassine in which he dissected the novel and identified five codes which, according to him, made up the entire narrative, thus producing an exhaustive analysis of the novella and a near scientific account of its constitutive elements (Barthes, 1974).

One impact of the structuralist approach to literature was that the study of literature lost its spiritual and moral dimension. This happened for two reasons: literary texts were analyzed as constituted by linguistic elements and not by some mystical and sacred phenomena; and the study of literature was conducted not for spiritual and moral uplift but for scientific analysis of literary works to determine their constitutive elements and general organization. These developments brought a major change in the conception and study of literature. On the one hand literature stood 'demystified' - it was now simply a composition in language which could be studied scientifically. On the other hand, the study of literature now set itself the task of developing a general understanding of literary works by carrying out a scientific study of literature instead of following the humanistic purpose of inculcating moral values through literary studies.

Though the Structuralist movement was itself challenged by Poststructuralim, the damage it had done to the Leavisite model of literary study continued to stay. This scientific approach to literature also displaced the cultural objectives of the literature programme. As discussed above, culture was literary language for Leavis, and if there was no such thing as a specifically 'literary language', then there also was no culture in the sense of refinement and taste. The privileged position literary works and their study had been given in the programme of literary studies instituted under Leavis's influence was now no longer tenable. Literary works were now considered as a part, and only a part, of the overall cultural activity, often defined as 'signifying practices', in a human society.

This was a complete reversal of the Leavis model of literary studies in which culture or society was to be shaped and governed by literature. Now it was culture that became the governing context of literary studies. A new discipline emerged to displace literary studies from its privileged position with regard to culture. The discipline was termed as cultural studies. The best description of this 'paradigm shift' in the study of literature comes from Anthony Easthope in his book Literary Into Cultural Studies. According to 
Easthope, "Yet in those fifty-three years [1930s to 1980s] modern literary studies was invented, institutionalized in the academy, fell into crisis, and is now being transformed into something else, cultural studies" (Easthope, 1991). Easthope (1991) further states that "the old [Leavisite] paradigm has collapsed, that the moment of crisis symptomatically registered in concern with theory is now passing, and that a fresh paradigm has emerged, its status as such proven because we can more or less agree on its terms and use them."

The discipline of literary studies, at this moment, finds itself in a crisis of identity. The study of literature today is strongly influenced by cultural and social theory and approaches like Marxism, Feminism, Historicism, Cultural Materialism, and Postcolonialism, approaches which have their origins and centres in disciplines and fields other than literature have become central to the study of literature. Moreover, these approaches are concerned with literary works only because literary works perform an illustrative function for them. Thus, a literary work gets to enjoy a certain prominence not because it has something called 'intrinsic artistic merit' but rather an illustrative potential, a usability which makes it a useful example to be cited for a social or cultural approach.

In one sense, this has not been an entirely negative development. The cultural studies paradigm has opened up the closed disciplinary boundaries of the social sciences and the humanities and there is a lot of very interesting and insightful work being produced through this interdisciplinary approach. According to Susan Hegeman, “... another way to look at the matter is to see the cultural turn as a particular moment in the history of interdisciplinary contact between the humanities and the social sciences" (Hegeman, 2012). In this situation the discipline of literature which in the Leavisite programme had become completely isolated from the larger social and cultural sphere has now extended its boundaries to include social and cultural theory and its application. In this opening up the study of literature has also responded to the pressures of marketability and the demands of the society from higher education institutes to provide socially empowering educational programmes. Literature graduates find employment in a number of fields such as journalism, advertising, publishing industry, civil service, electronic media and other related fields.

However, the cultural turn in literary studies has created a major problem for literary scholars and academics. The discipline of cultural studies has, in a sense, not only developed out of literary studies but against it, particularly against its commitment to the literary canon. Where literary studies were established on elitist grounds, as is evident from Leavis's Mass Civilization and Minority Culture, the discipline of Cultural Studies aims at being democratic and celebrates popular culture. Moreover, the cultural turn in its political form has brought about an opening of the literary canon and has made it more inclusive. The literary canon today is not exclusively European or American, but includes works by major writers from other regions of the world.

Many literary scholars have seen these developments as inimical to literary studies. The most prominent among them is Harold Bloom who in his book The Western Canon has tried to uphold the traditional canon of literary works. Bloom's and other scholars' 
concern is that the literary canon has to be formed strictly on the basis of literary merits or aesthetic value and not on political or cultural grounds. According to Harold Bloom, "Nothing is so essential to the Western Canon as its principles of selectivity, which are elitist only to the extent that they are founded upon severely artistic criteria" (Bloom, 1994). Noting that "[t]he flight from or the repression of the aesthetic is endemic in our institutions of what will purport to be higher education," Bloom (1994) asserts that "[o]ne breaks into the canon only by aesthetic strength, which is constituted primarily of an amalgam: mastery of figurative language, originality, cognitive power, knowledge, exuberance of diction." Emphasizing the necessity of the canon, Bloom (1994) states, "Without the Canon we cease to think. You may idealize endlessly about replacing aesthetic standards with ethnocentric and gender considerations and your social aims may indeed be admirable. Yet only strength can join itself to strength, as Nietzsche perpetually testified."

Bloom is not entirely wrong in insisting upon the primacy of aesthetic criteria in the formation of the canon. If literary works are evaluated solely by political or cultural concerns, then the quality of literary works themselves will suffer. Any writer will have a claim upon the canon if he or she just writes in a politically correct way, or writes about a politically or culturally relevant theme. To some scholars, this is the very thing that has happened. The distinction between good and bad literature is no longer easy to make or defend. All such moves are declared to be ideological, made either from a patriarchal or bourgeois or colonial position. It is this situation which prompted Rene Wellek to write the following words:

Today this whole edifice of literary study has come under an attack that is not merely the normal criticism of certain aspects of a changing discipline but an attempt to destroy literary studies from the inside. (Wellek, 1983/2005)

The only possible solution to this crisis in literary studies seems to be a return to the aesthetic. The traditional understanding of the aesthetic is a Romantic one and derived from Kant. Yet in the our post-secular world, the aesthetic is increasingly being aligned to the religious. Robert Eaglestone has discussed the connection between religion and an emerging field of study called 'The New Aestheticism'. Noting the similarity between religious experiences and the experience of art, Eaglestone writes:

\footnotetext{
The sorts of things that 'this painting knows' are rarely, say, reducible to positivistic assertions; they typically throw us back on our existential selfunderstandings of our own being in the world: the need for and fear of decision, our complex and uncertain sense of right and wrong, desire and love, our relation to our own extinction and so on. Are these experiences religious? Well, the discourse of religion certainly speaks to them. But they are also literary experiences, both portrayed in literature and enacted, in ways, by literature ... Are these experiences, brought under the eye of philosophy, religious experiences or are they human experiences understood religiously? (Eaglestone, 2009)
}

Thus, literary works today carry a strong religious and spiritual meaning for their writers and readers. However, the spiritual aspect of literary works, the aspect that makes them 
meaningful to a large number of readers, finds little or no reflection in their academic study. In the absence of a critical engagement with questions of spirituality, a lot of literature being produced today is no better in quality than the 'self-help' books also being produced in great abundance. It is, therefore, imperative to seek a possibility, to develop an approach, that can create the space for discussion of spiritual questions in literary studies. In the final section of this paper I would like to suggest such an approach which has the potential to establish the spiritual dimension in the study of literature on definite grounds.

In two of his research papers, one on crisis in the humanities and the other on an approach to Romanticism Dr Iftikhar Shafi, a literary scholar who specializes in comparative literature particularly in the poetry of Rumi, has shown theoretically and practically how such an approach can be developed and applied. The approach suggested by Shafi is comparative. Noting first some similarities and then establishing the difference between the Sufi tradition and some contemporary understandings of literature in his paper "Addressing Disciplinary Crisis in Comparative Literature the Sufi Way", Dr Shafi writes, "The tradition of Tasawwuf has much to offer by way of realigning our institutional and pedagogical practices in literature ... One important point that the present crisis-hit literary practice can learn from it is not to let its institutional values be drawn and determined by the market-place" (Shafi, 2010). In Shafi's view, "The over intellectualization of the discipline has to a large extent been a symptom of the literary academic's giving in to the pressures of competition between various social sciences, to carve out a specialized jargon for the discipline in order to maintain its "corporate visibility"' (2010). Compared to Arnold's conception of poetry as a sort of substitute for religion, Shafi defines the Sufi approach to poetry in these words:

To put it otherwise, the Sufi poetics falls within the larger system of Sufi thought and practice. Poetry no doubt has been considered in this tradition as performing a religious function but has never made any claims of supplanting religion itself; it derives its inspiration from the Prophetic revelation but knows well that the Prophetic revelation is not "unconscious poetry." In the hierarchy of values in the life of a Sufi, poetry has its own place, which is undoubtedly subservient to that of religion. (Shafi, 2010)

In a paper presented at the International Conference on Language and Literature, entitled "Why and How to Read Romanticism: Instruction for a Pakistani Student of Literature and Culture" Shafi has demonstrated how a comparative reading of Sufism and Romanticism leads to an enhanced understanding of Romanticism. Setting out the objectives of his paper in the first section, Shafi writes:

It suggests that it is primarily through a comparative approach that European Romanticism can become a maqâm-e- 'ibrat or a "scene of instruction" for a Pakistani student of literature and culture. The primary aim of a Pakistani student of literature and culture, the paper maintains, should be an attempt to identify, understand and possibly resolve the intricate issues related to the Pakistani critical and cultural matrix, its development (or degeneration) into a predicament-like situation. Reading Romanticism in a particularly comparative 
mode suggested here may allow a Pakistani reader to move in the direction of achieving such an aim. (Shafi, Why and How to Read Romanticism, 2014)

In this paper Shafi has discussed some key elements of Romanticism such as dream, heart-break, dejection, wandering, which are often considered to be present in the Sufi tradition as well. However, he has shown these elements as treated very differently in the two traditions. In the Romantic tradition, heart-break for example, is a sign of failure and defeat and it leads to dejection. While in the Sufi tradition heart-break is a painful but necessary experience of coming to self knowledge and the knowledge of God. After establishing these differences, Shafi defines the comparative approach to the study of literature as a necessity for Pakistani students of literature. He writes:

\begin{abstract}
'Ibrah as a mode of comparative reading can only work for the contemporary students of literature and culture in Pakistan, especially English literature, if the students are deeply grounded, body and soul, in what Faiz calls "their own literatures." They have a double duty, to deal with two traditions that are tantalizingly close and yet distant from each other, and within this difficult space of "the near and the far" locate their own cultural existence. (Shafi, Why and How to Read Romanticism, 2014)
\end{abstract}

This comparative approach brings a great deal of clarity and order to the study of the spiritual and religious elements in literature. According to Philip Sheldrake (2007), "The contemporary use of the word 'spirituality' is sometimes vague and difficult to define precisely because it is increasingly detached from religious traditions ...." Instead of talking in vague and obscure terms about spiritual and mystical experiences, the reference to a religious tradition provides a framework within which or alongside which we can make sense of experiences which are not graspable through a purely rational and scientific inquiry.

In conclusion I would like to state that these are times of rapid change and transformation. The understanding of our own times as post-secular compels us to revisit some of the key issues that have shaped the discipline of literary studies. T.S. Eliot once stated that "literary criticism should be completed by criticism from a definite ethical and theological standpoint" (Eliot, 1975). As the paper has established, this 'definite ethical and theological standpoint' is indispensable for any concrete and effective discussion of 'spirituality' and that Sufism provides one such standpoint from which to approach questions of spirituality and religion in literature.

\title{
References
}

Arnold, M. (2004). The Study of Poetry. In H. Adams, \& L. Searle (Eds.), Critical Theory Since Plato (3rd ed., pp. 599-603). Belmont, California: Wadsworth Publishing Company.

Barthes, R. (1974). S/Z. (R. Miller, Trans.) New York: Farrar, Straus and Giroux.

Bloom, H. (1994). The Western Canon. Orlando, Florida: Harcourt Brace and Company. 
Eaglestone, R. (2009). Religion, Truth and the 'New Aestheticism. In M. Knight, \& L. Lee (Eds.), Religion, Literature and the Imagination: Sacred Worlds (pp. 37-46). London and New York: Continuum.

Easthope, A. (1991). Literary Into Cultural Studies. London and New York: Routledge.

Eliot, T. (1975). Religion and Literature. New York: Harcourt Brace Jovanovich.

Felperin, H. (1985). Beyond Deconstruction: The Uses and Abuses of Literary Theory. New York: Oxford University Press.

Garnett, J. (2006). Introduction. In M. Arnold, Culture and Anarchy (pp. vii-xxviii). New York: Oxford University Press.

Hegeman, S. (2012). The Cultural Return. Berkley and Los Angeles: University of California Press.

Leavis, F. (1997). Literary Criticism and Philosophy. In K. Newton (Ed.), Twentieth Century Literary Theory: A Reader (2nd ed., pp. 37-40). New York: St. Martin's Press. (Original work published 1937)

Leavis, F. (2009). Mass Civilization and Minority Culture. In R. Storer, F.R. Leavis (pp. 45-49). New York: Routledge. (Original work published 1930)

Prickett, S. (1990). Biblical Hermeneutics. In M. Coyle, P. Garside, M. Kelsall, \& J. Peck (Eds.), Encyclopedia of Literature and Criticism (pp. 653-665). London: Routledge.

Said, E. (1994). Culture and Imperialism. New York: Vintage Books.

Shafi, I. (2010). Aymani Bugzâr-o-Jâye Khawf Bâsh: Addressing Disciplinary Crisis in Comparative Literature the Sufi Way. Tamkung Review , 40 (2), 151-175.

Shafi, I. (2014, April). Why and How to Read Romanticism: Instruction for a Pakistani Student of Literature and Culture. Paper presented at First International Conference on Language and Literature at Government College Lahore University, Lahore, Pakistan.

Sheldrake, P. (2007). A Brief History of Spirituality. Malden, MA: Blackwell Publishing.

Wellek, R. (2005). Destroying Literary Studies. In D. Patai, \& W. H. Corral (Eds.), Theory's Empire: An Anthology of Dissent (pp. 41-52). New York: Columbia University Press. (Original work published 1983) 